\title{
Changes in sorbitol, myo-inositol and lipid inositol in dorsal root and sympathetic ganglia from streptozotocin-diabetic rats
}

\author{
J. G. Llewelyn ${ }^{1}$, C. M. F. Simpson ${ }^{2}$, P. K. Thomas ${ }^{1}$, R. H. M. King ${ }^{1}$ and J. N. Hawthorne ${ }^{2}$ \\ ${ }^{1}$ Department of Neurological Science, Royal Free Hospital School of Medicine, London and \\ ${ }^{2}$ Department of Biochemistry, Medical School, University of Nottingham, Nottingham, UK
}

\begin{abstract}
Summary. Sorbitol, fructose, myo-inositol and lipid inositol concentrations were measured in excised dorsal root and sympathetic ganglia from rats with streptozotocin-induced diabetes, both in the acute stage ( 1 and 2 weeks after the induction of diabetes) and chronically (after 2 months of diabetes). In comparison with age-matched controls, myo-inositol concentrations were decreased by $26-32 \%$ after 1 and 2 weeks but had returned to normal levels at 2 months. Lipid inositol concentrations were normal both in the acutely and chronically diabetic animals. Sorbitol was not detectable in ganglia from diabetic or control animals except for a small quantity
\end{abstract}

( $0.05 \mu \mathrm{mol} / \mathrm{g}$ wet weight) in dorsal root ganglia at the 2-month stage. Fructose was present in dorsal root ganglia $(1.71-3.53 \mu \mathrm{mol} / \mathrm{g}$ wet weight) at all stages and in sympathetic ganglia $(2.18 \mu \mathrm{mol} / \mathrm{g}$ wet weight $)$ at the 8 -week stage. The differences in these results from those obtained in peripheral nerve trunks are possibly related to the lack of a blood-nerve barrier in sensory and autonomic ganglia.

Key words: Streptozotocin diabetes, dorsal root and sympathetic ganglia, sorbitol, fructose, myo-inositol.
The carbohydrate metabolism of peripheral nerve resembles that of the central nervous system in that it is largely determined by exogenous glucose and independent of insulin control [1]. This is probably related to the fact that both are isolated by blood-nerve and bloodbrain barriers respectively, which restrict access of substrates. Glucose is able to enter nerve freely, but nevertheless resting energy utilization in experimental diabetes is reduced by $25-30 \%$ despite elevated glucose concentrations [2]. This has been attributed to reduced $\mathrm{Na}^{+} \mathrm{K}^{+}$-ATPase activity [3], which is known to exist in diabetic nerve [4-6]. A major component of energy utilization in nerve occurs via $\mathrm{Na}^{+} \mathrm{K}^{+}$-ATPase. It has further been suggested that the reduced $\mathrm{Na}^{+} \mathrm{K}^{+}$-ATPase activity is related to altered $m y o$-inositol metabolism. Myo-inositol is actively transported into nerve by an $\mathrm{Na}^{+}$-dependent carrier mechanism [7]; a concentration in nerve approximately 100 times that of plasma is maintained. This is reduced in the presence of hyperglycaemia both in human $[8]$ and experimental $[9,10]$ diabetes. The reduced $\mathrm{Na}^{+} \mathrm{K}^{+}$-ATPase activity can be prevented by $m y o$-inositol supplementation [5]. A possible mechanism for the regulation of $\mathrm{Na}^{+} \mathrm{K}^{+}$-ATPase activity has recently been proposed by Greene and Lattimer [11]. $M y o$-inositol is incorporated into membrane phospholipids. Inositol phospholipid turnover releases inositol trisphosphate $\left(\mathrm{IP}_{3}\right)$ and diacylglycerol (DG), both putative 'second messengers'. DG regulates protein kinase $\mathrm{C}$ activity. It was found, in peripheral nerve from alloxan-diabetic rabbits, that protein kinase $\mathrm{C}$ activators normalize ouabain-inhibitable respiration, which in nerve is an expression of $\mathrm{Na}^{+} \mathrm{K}^{+}$-ATPase activity. This suggests that the reduced $\mathrm{Na}^{+} \mathrm{K}^{+}$-ATPase activity is secondary to the impaired myo-inositol and phosphoinositide metabolism.

A further major metabolic abnormality in diabetic nerve is the accumulation of sorbitol. Peripheral nerve possesses a sorbitol pathway in which glucose is converted to sorbitol by aldose reductase and then sorbitol to fructose by sorbitol dehydrogenase. This pathway is augmented in the presence of hyperglycaemia, leading to the accumulation of sorbitol and fructose in nerve. The accumulation of sorbitol may contribute to the reduced myo-inositol concentration in nerve since lowering sorbitol concentrations by aldose reductase inhibition restores myo-inositol to normal in diabetic rats [12, 13]. How sorbitol and inositol are linked is not clear, but sorbitol does not directly interfere with inositol uptake $[13,14]$.

Dorsal root and autonomic ganglia differ from peripheral nerve trunks in that the blood-nerve barrier is deficient [15-17]. The metabolic abnormalities that oc- 
cur in these ganglia in diabetes have not yet been investigated in detail, although in dorsal root ganglia from streptozotocin-diabetic rats amino acid uptake has been shown to be reduced [18] and $\mathrm{Na}^{+} \mathrm{K}^{+}$-ATPase activity to be diminished [19]. Alterations in the content of sorbitol and myo-inositol have not so far been studied, but in the absence of an effective blood-nerve barrier, it is conceivable that the changes may differ from those that have been demonstrated in peripheral nerve trunks. This investigation was therefore undertaken to examine the alterations that occur in the dorsal root and sympathetic ganglia, both in acute and chronic streptozotocininduced diabetes in the rat.

\section{Materials and methods}

\section{Animal preparation}

Diabetes was induced in mature male Wistar rats, aged 9-10 weeks, weighing $300-350 \mathrm{~g}$, by the injection of a buffered solution of streptozotocin into the tail vein at a dosage of $65 \mathrm{mg} / \mathrm{kg}$ body weight. Control rats were administered an equivalent quantity of sterile physiological $\mathrm{NaCl}$ solution $(150 \mathrm{mmol} / 1)$.

Diabetic and control animals were housed separately in plastic metabolic cages and fed on 41B Oxoid diet (Oxoid, Basingstoke, Hants, UK) with water ad libitum. The myo-inositol content of the diet was $0.022 \%$ by weight. Both groups were weighed regularly and the diabetic rats checked for glycosuria. The diabetic animals all developed glycosuria in excess of $2 \%$ within a few days of the administration of streptozotocin and progressively lost weight. Two experiments were performed. In the first, ganglia were obtained from animals at intervals of 1,2 and 8 weeks after the induction of diabetes. In the second experiment, ganglia were obtained after intervals of 2 and 8 weeks. When anaesthetized for the collection of ganglia, a venous blood sample was taken and plasma glucose determined on a Beckman Glucose Analyser II (Beckman, Fullerton, Calif., USA).

\section{Tissue collection}

Under general anaesthesia with halothane (ICI, Macclesfield, UK) and oxygen inhalation, laminectomy was performed. In the first experiment, the lumbar and lower thoracic pairs of dorsal root ganglia were excised under an operating microsope (Zeiss, Jena, DDR). The ventral roots were removed and the dorsal roots trimmed close to the proximal and distal ends of the ganglia. Any visible surrounding connective tissue was detached. The ganglia were put into small plastic containers and placed in liquid nitrogen immediately after removal.

In the second experiment, in addition to the dorsal root ganglia, the ganglia from the cervical sympathetic chain were taken from both sides of the neck.

\section{Biochemical assays}

Weighed samples (dorsal root ganglia, $6.3-18 \mathrm{mg}$ wet weight; sympathetic ganglia $1.3-4.3 \mathrm{mg}$ wet weight) were homogenized in $1.5 \mathrm{ml}$ distilled $\mathrm{H}_{2} \mathrm{O}: 0.17 \mathrm{~mol} / 1 \mathrm{ZnSO}_{4}: 0.15 \mathrm{~mol} / 1 \mathrm{Ba}(\mathrm{OH})_{2}$ (13:1:1 by volume) and the supernatant lyophilized with $50 \mu \mathrm{g}$ of $\alpha$-methyl-D-mannoside as an internal standard. The $\mathrm{ZnSO}_{4} / \mathrm{Ba}(\mathrm{OH})_{2}$ precipitates were washed with $1.5 \mathrm{ml}$ distilled $\mathrm{H}_{2} \mathrm{O}$ and the phospholipid extracted by the method of Griffin and Hawthorne [20]. The lipid extracts were then transferred to glass ampoules and dried under a stream of nitrogen.

Inositol was released from the phospholipid by acid hydrolysis in sealed ampoules at $120^{\circ} \mathrm{C}$ for $20 \mathrm{~h}$ using $1 \mathrm{ml}$ of $6 \mathrm{~mol} / 1 \mathrm{HCl}$ added to

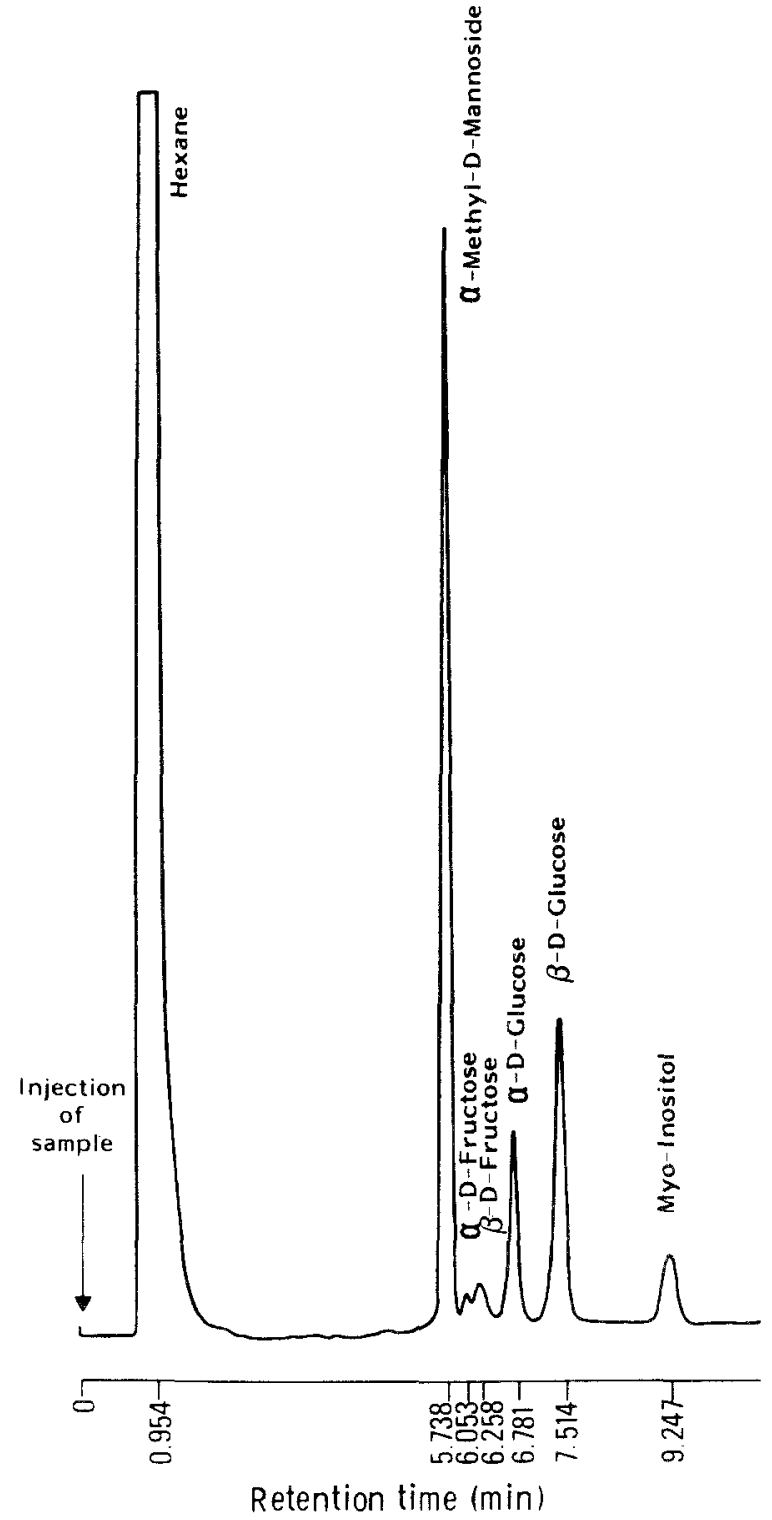

Fig.1. A typical gas-liquid chromatography separation of trimethylsilyl ether derivatives of sugars and sugar alcohols extracted from the dorsal root ganglia after 2 weeks of streptozotocin-induced diabetes. Programme conditions are described in the text

each sample. The acid was then evaporated and the free inositol extracted with $3 \times 1 \mathrm{ml}$ distilled $\mathrm{H}_{2} \mathrm{O} .50 \mu \mathrm{g}$ of $\alpha$-methyl-D-mannoside was added to each extract and the samples lyophilized.

Free sugars and sugar alcohols in the lyophilized extracts were converted into their trimethylsilyl ether derivatives [21] by reaction with $200 \mu \mathrm{l}$ of pyridine/hexamethyldisilazane/trimethylchlorosilane (10:2:1 by volume) for $15 \mathrm{~min}$ at room temperature. The yield of trimethylsilyl ether derivatives does not alter with incubation times ranging from $10 \mathrm{~min}$ to $18 \mathrm{~h}$.

Samples were analysed using a Perkin Elmer 8310 gas-liquid chromatograph equipped with a stainless steel, glass-lined column $2 \mathrm{~m}$ in length with an internal diameter of $3 \mathrm{~mm}$ and packed with Chromosorb WHP (80-100 mesh) coated with 3\% SE-30.

The samples were injected at $250^{\circ} \mathrm{C}$ and the flame ionization detector was operated at $300^{\circ} \mathrm{C}$. The column was maintained at $195^{\circ} \mathrm{C}$ for $2 \mathrm{~min}$ after injection, and the temperature subsequently increased at a rate of $15^{\circ} \mathrm{C} / \mathrm{min}$ to a final temperature of $250^{\circ} \mathrm{C}$ which was maintained for 5 min. Component peaks (Fig. 1) were identified by reference to known standards and quantification effected by relating peak area of the sugar to that of the internal standard. 
Table 1. Body weight and plasma glucose values at termination of experiment for age-matched controls and diabetic animals (means \pm SD)

\begin{tabular}{llll}
\hline & $\begin{array}{l}\text { Duration of } \\
\text { diabetes }\end{array}$ & $\begin{array}{l}\text { Body weight } \\
(\mathrm{g})\end{array}$ & $\begin{array}{l}\text { Plasma glucose } \\
(\mathrm{mmol} / \mathrm{l})\end{array}$ \\
\hline $\begin{array}{l}\text { First experiment } \\
\text { Control (12) }\end{array}$ & 1 week & $380.8 \pm 4.7$ & $12.2 \pm 1.0$ \\
$\begin{array}{c}\text { Diabetic (13) } \\
\text { Control (12) }\end{array}$ & 2 weeks & $304.8 \pm 5.4$ & $34.7 \pm 2.9$ \\
Diabetic (12) & & $287.2 \pm 4.8$ & $11.1 \pm 1.1$ \\
Control (13) & 8 weeks & $483.3 \pm 8.8$ & $11.4 \pm 1.6$ \\
Diabetic (14) & & $225.5 \pm 6.3$ & $40.7 \pm 2.2$ \\
& & & \\
Second experiment & & $368.8 \pm 11.2$ & $10.6 \pm 1.5$ \\
Control (8) & 2 weeks & $251.9 \pm 10.5$ & $40.7 \pm 1.4$ \\
Diabetic (9) & & $475.3 \pm 13.5$ & $12.2 \pm 0.6$ \\
$\begin{array}{l}\text { Control (7) } \\
\text { Diabetic (14) }\end{array}$ & 8 weeks & $219.4 \pm 7.5$ & $42.3 \pm 2.3$ \\
\hline
\end{tabular}

Number of animals in each group given in parenthesis

Table 2. Concentrations of glucose, myo-inositol, sorbitol and fructose (in $\mu \mathrm{mol} / \mathrm{g}$ wet weight) for dorsal root ganglia from diabetic and age-matched control rats. Experiment 1

\begin{tabular}{|c|c|c|c|c|}
\hline & Glucose & $\begin{array}{l}\text { Myo- } \\
\text { inositol }\end{array}$ & Sorbitol & Fructose \\
\hline \multicolumn{5}{|c|}{1 week after induction of diabetes } \\
\hline Control (12) & $\mathrm{ND}$ & $3.04 \pm 0.54$ & ND & ND \\
\hline Diabetic (12) & $5.70 \pm 1.90$ & $\begin{array}{l}2.25 \pm 0.24 \\
p<0.001\end{array}$ & ND & $1.71 \pm 0.37$ \\
\hline \multicolumn{5}{|c|}{2 weeks after induction of diabetes } \\
\hline Control (12) & $\mathrm{ND}$ & $3.04 \pm 0.37$ & ND & ND \\
\hline Diabetic (10) & $6.75 \pm 1.55$ & $\begin{array}{l}2.26 \pm 0.42 \\
p<0.001\end{array}$ & ND & $1.97 \pm 0.41$ \\
\hline \multicolumn{5}{|c|}{8 weeks after induction of diabetes } \\
\hline Control (12) & ND & $3.02 \pm 0.39$ & ND & ND \\
\hline Diabetic (14) & $11.93 \pm 2.84$ & $\begin{array}{l}3.09 \pm 0.84 \\
\text { NS }\end{array}$ & $0.05 \pm 0.02$ & $2.81 \pm 0.32$ \\
\hline
\end{tabular}

Number of animals in each group given in parenthesis. ND = not detected. $\mathrm{NS}=$ not significant. Means $\pm \mathrm{SD}$

Table 3. Concentrations of glucose, myo-inositol, sorbitol and fructose (in $\mu \mathrm{mol} / \mathrm{g}$ wet weight) for dorsal root ganglia from diabetic and age-matched control rats. Experiment 2

\begin{tabular}{|c|c|c|c|c|}
\hline & Glucose & $\begin{array}{l}\text { Myo- } \\
\text { inositol }\end{array}$ & Sorbitol & Fructose \\
\hline \multicolumn{5}{|c|}{2 weeks after induction of diabetes } \\
\hline Control (8) & $\mathrm{ND}$ & $3.52 \pm 0.42$ & ND & ND \\
\hline Diabetic (8) & $12.91 \pm 3.15$ & $\begin{array}{l}2.44 \pm 0.41 \\
p<0.001\end{array}$ & $\mathrm{ND}$ & $3.06 \pm 0.90$ \\
\hline \multicolumn{5}{|c|}{8 weeks after induction of diabetes } \\
\hline Control (7) & $\mathrm{ND}$ & $3.61 \pm 0.37$ & ND & ND \\
\hline Diabetic (10) & $14.23 \pm 3.56$ & $\begin{array}{l}3.04 \pm 0.72 \\
\text { NS }\end{array}$ & ND & $3.53 \pm 0.85$ \\
\hline
\end{tabular}

Number of animals in each group given in parenthesis. ND $=$ not detected. $\mathrm{NS}=$ not significant. Means \pm SD

\section{Statistical analysis}

The comparisons between the diabetic and control animals were made on mean values using Student's t-test for unpaired data. The results are expressed as means $\pm \mathrm{SD}$. A statistically significant difference was accepted for $p<0.05$.

\section{Results}

The mean values for body weight and plasma glucose concentration at the termination of the experiment for the different groups are given in Table 1. Histological examination of ganglia obtained in a pilot study showed that the ganglia had been excised together with their capsules, but without any significant surrounding tissue and, in particular, no epineurial fat.

\section{Dorsal root ganglia}

The results for tissue glucose, myo-inositol, sorbitol and fructose estimations for the dorsal root ganglia from the first experiment are displayed in Table 2 . These show a significant reduction in the $m y o$-inositol content at the 1 - and 2-week survival periods ( $p<0.001$ ), but not at 8 weeks. Sorbitol and fructose were not detected in the control animals at any stage. In the diabetic animals, sorbitol was not detected at the 1- and 2-week stages; a small quantity was present at 8 weeks. Fructose was present at all three stages.

The results for the second experiment, which was restricted to 2 and 8 week survival periods, are given in Table 3. The results obtained were consistent with those of the first experiment. There was again a significant reduction in myo-inositol concentration at 2 weeks $p<$ 0.001 but not at 8 weeks. Sorbitol was not detected in the control or diabetic ganglia at either stage. Fructose was present in the diabetic ganglia at both the 2- and 8-week stages.

Observations on lipid inositol concentrations were made only in the second experiment. The results obtained are shown in Table 4. No significant differences were detected between the diabetic and control animals at either the 2-or 8-week stages.

\section{Sympathetic ganglia}

The values for the cervical sympathetic ganglia are given in Table 5. Although the weights for the ganglia were low, the pattern of the results was identical to that obtained for the dorsal root ganglia. There was a significant reduction in myo-inositol concentration after 2 weeks of diabetes $(p<0.05)$ but not at 8 weeks. Sorbitol was not detected in the diabetic animals at either stage, but fructose was present at 8 weeks. Lipid inositol concentrations did not differ between the diabetic and control animals either at the 2-week or the 8-week stages (Table 4). 
Table 4. Concentrations of lipid inositol (in $\mu \mathrm{mol} / \mathrm{g}$ wet weight) from dorsal root and sympathetic ganglia from diabetic and age-matched control rats

\begin{tabular}{lll}
\hline & $\begin{array}{l}\text { 2 weeks after } \\
\text { induction of diabetes }\end{array}$ & $\begin{array}{l}\text { 8 weeks after } \\
\text { induction of diabetes }\end{array}$ \\
\hline $\begin{array}{l}\text { Dorsal root ganglia } \\
\text { Control }\end{array}$ & $1.11 \pm 0.25(8)$ & $1.04 \pm 0.32(6)$ \\
Diabetic & $1.19 \pm 0.21(8)$ & $0.91 \pm 0.26(8)$ \\
& NS & NS \\
Sympathetic ganglia & \\
Control & $0.96 \pm 0.27(5)$ & $0.73 \pm 0.17(6)$ \\
Diabetic & $0.86 \pm 0.10(7)$ & $0.91 \pm 0.22(10)$ \\
& NS & NS
\end{tabular}

Number of animals in each group given in parenthesis. NS $=$ not significant. Means $\pm S D$

Table 5. Concentrations of glucose, myo-inositol, sorbitol and fructose (in $\mu \mathrm{mol} / \mathrm{g}$ wet weight) for cervical sympathetic ganglia from diabetic and age-matched control rats

\begin{tabular}{|c|c|c|c|c|}
\hline & Glucose & $\begin{array}{l}\text { Myo- } \\
\text { inositol }\end{array}$ & Sorbitol & Fructose \\
\hline \multicolumn{5}{|c|}{$\begin{array}{l}2 \text { weeks after } \\
\text { induction of diabetes }\end{array}$} \\
\hline Control (8) & $\mathrm{ND}$ & $6.04 \pm 1.40$ & ND & ND \\
\hline Diabetic (9) & $17.31 \pm 4.77$ & $\begin{array}{l}4.43 \pm 1.41 \\
p<0.05\end{array}$ & $\mathrm{ND}$ & ND \\
\hline \multicolumn{5}{|c|}{$\begin{array}{l}8 \text { weeks after } \\
\text { induction of diabetes }\end{array}$} \\
\hline Control (7) & ND & $4.78 \pm 1.50$ & $\mathrm{ND}$ & ND \\
\hline Diabetic (14) & $25.01 \pm 6.39$ & $\begin{array}{l}4.83 \pm 1.06 \\
\text { NS }\end{array}$ & ND & $2.18 \pm 0.50$ \\
\hline
\end{tabular}

Number of animals in each group given in parenthesis. ND $=$ not detected. $\mathrm{NS}=$ not significant. Means $\pm \mathrm{SD}$

\section{Discussion}

The metabolic alterations that occur in rat dorsal root and autonomic ganglia in the first 2 months after the induction of diabetes clearly differ from those in the peripheral nerve trunks. The changes in sorbitol and fructose concentrations resemble those seen in the spinal cord and brain [22]. Within the central nervous system (CNS) an enzyme of the glucuronic acid-xylulose shunt, NADP L-hexonate dehydrogenase, predominates, although small amounts of aldose reductase are found. Hexonate dehydrogenase catalyses the reduction of a range of substrates similar to those of aldose reductase, though the latter has a much lower $\mathrm{Km}$ for the conversion of hexoses to sugar alcohols. In the presence of high ambient tissue glucose levels, however, hexonate dehydrogenase can form sorbitol in small amounts [23]. Sorbitol dehydrogenase activity may be present in ganglia, as in CNS issue, to produce fructose from sorbitol. If the activity of this enzyme were high in ganglia, there could be significant polyol pathway activity with little or no accumulation of sorbitol. This possibility could be further investigated by treating the animals with an al- dose reductase inhibitor. Other factors could contribute to the lack of any marked accumulation of sorbitol and fructose in diabetic ganglia, such as the absence of a blood-nerve barrier in contradistinction to peripheral nerve trunks. The barrier in nerve depends upon the presence of tight junctions between the endothelial cells of endoneurial capillaries [15]. In the dorsal root and sympathetic ganglia the capillaries are fenestrated [16, 17], allowing for the free diffusion of substances in the endoneurial fluid out of the ganglia.

The concentration of myo-inositol in both dorsal root and sympathetic ganglia was reduced in the acutely diabetic animals. This was only temporary. At the 8 week survival time, myo-inositol concentrations did not differ significantly between diabetic and control animals. Lipid inositol concentrations did not differ either at the 2- or 8-week stages, although more subtle changes in inositol phospholipid metabolism would not necessarily have been detected. It would seem therefore that reduced myo-inositol levels over a prolonged period may occur only in association with raised tissue sorbitol concentrations. The metabolic abnormalities that develop in peripheral nerve in streptozotocin-diabetic animals are not the result of streptozotocin toxicity as they are reversed by treatment with insulin [9]. There is no reason to suspect that ganglia would differ.

$\mathrm{Na}^{+} \mathrm{K}^{+}$-ATPase activity is known to be reduced in peripheral nerve in diabetic animals $[4-6]$ and, as stated in the introduction, it has been suggested that the activity of this enzyme is controlled by myo-inositol and phosphoinositide metabolism, via protein kinase C [11]. This evidence is indirect, and as yet no protein phosphorylation has been demonstrated. We previously found that $\mathrm{Na}^{+} \mathrm{K}^{+}$-ATPase activity is reduced in the dorsal root ganglia of streptozotocin-diabetic rats [9]. This was at 8 weeks after the induction of diabetes when, as demonstrated in the present study, myo-inositol and lipid inositol concentrations are normal. Some other explanation is therefore required for the reduced $\mathrm{Na}^{+} \mathrm{K}^{+}$-ATPase activity in ganglia. A number of possibilities present themselves: (1) Membrane fluidity influences the activity of membrane-associated enzymes, including $\mathrm{Na}^{+} \mathrm{K}^{+}$-ATPase [24]. Membrane fluidity may be altered in diabetes $[25,26]$, although this has not yet been examined for peripheral nerve. (2) In tissue culture, nerve growth factor has been shown to regulate $\mathrm{Na}^{+} \mathrm{K}^{+}$-ATPase activity in dorsal root ganglia [27], but it is not known whether this is important in vivo in mature animals. The retrograde transport of nerve growth factor by axons is impaired in experimentally diabetic animals [28]. (3) If $\mathrm{Na}^{+} \mathrm{K}^{+}$-ATPase activity in dorsal root ganglia, as suggested for peripheral nerve [11], is modulated by protein kinase $\mathrm{C}$, it is possible that in ganglia protein kinase $\mathrm{C}$ activity can be affected by a mechanism other than via myo-inositol metabolism. It would thus be of interest to establish whether the reduced $\mathrm{Na}^{+} \mathrm{K}^{+}$-ATPase activity in ganglia can be corrected by protein kinase $\mathrm{C}$ agonists. (4) The possibility 
of circulating inhibitors of $\mathrm{Na}^{+} \mathrm{K}^{+}$-ATPase activity, analogous with those that develop in hepatic failure [29], might be considered. (5) It has not yet been established whether, in streptozotocin-induced diabetes, there is a reduction in the amount of $\mathrm{Na}^{+} \mathrm{K}^{+}$-ATPase or whether it is the activity of this membrane-associated enzyme that is reduced. If total ATPase rather than its activity is reduced, impaired synthesis or increased degradation could be implicated.

The observation that the decrease in myo-inositol appears to be transient in dorsal root and sympathetic ganglia requires comment. The possible chain of events may be as follows: (1) Competition with glucose for inositol carrier results in a decrease in intracellular myoinositol concentration. (2) This initial decrease in intracellular myo-inositol may be linked to reduced $\mathrm{Na}^{+} \mathrm{K}^{+}$-ATPase activity. (3) Inositol uptake is sodiumlinked, and therefore reduced $\mathrm{Na}^{+} \mathrm{K}^{+}$-ATPase activity may lead to a further reduction in myo-inositol uptake. (4) Endogenous inositol synthesis may be switched on when the level of intracellular myo-inositol decreases below a certain threshold, resulting in recovery of inositol concentration, However, the possibility has to be considered that the recovery of tissue inositol levels does not fully restore the more specific smaller phosphatidylinositol pools, whose rapid turnover has been postulated to play a part in the control of $\mathrm{Na}^{+} \mathrm{K}^{+}$ATPase activity [30, 31].

The metabolic changes in the dorsal root and autonomic ganglia in experimental diabetes could be of relevance for human diabetic neuropathy. Although vascular and mechanical factors are likely to be important in the focal and multifocal nerve lesions that occur, the commonest type of diabetic neuropathy is a sensory and autonomic polyneuropathy [32]. A process that selectively affects the cells of the dorsal root and autonomic ganglia, with relative sparing of the anterior horn cells which are within the central nervous system, therefore deserves consideration.

Acknowledgements. This work was supported by a generous grant from Pfizer Ltd. to P. K. T. and J. N. H. J.G.L. and C.M.F.S. are Pfizer Research Fellows. The streptozotocin was kindly provided by the Drug Development Branch, National Institutes of Health, Bethesda, Md, USA. We are also indebted to the Department of Chemical Pathology and Human Metabolism, Royal Free Hospital School of Medicine, for the blood glucose estimations.

\section{References}

1. Brown MJ, Greene DA (1984) Diabetic neuropathy: pathophysiology and management. In: Asbury AK, Gilliatt RW (eds) Peripheral nerve disorders. Butterworths, London, pp 126-153

2. Greene DA, Winegrad AI (1981) Effects of acute experimental diabetes on composite energy metabolism in peripheral nerve axons and Schwann cells. Diabetes 30:967-974

3. Greene DA, Lattimer SA (1983) A self-reinforcing metabolic defect in diabetic peripheral nerve involving myo-inositol and the sodium-potassium ATPase. Clin Res 31: 501A
4. Das PK, Bray GM, Aguayo AJ, Rasminsky M (1976) Diminished ouabain-sensitive, sodium-potassium ATPase activity in sciatic nerves of rats with streptozotocin-induced diabetes. Exp Neurol 53: $285-288$

5. Greene DA, Lattimer SA (1983) Impaired rat sciatic nerve sodiumpotassium adenosine triphosphatase in acute streptozotocin diabetes and its correction by dietary myoinositol supplementation. $\mathbf{J}$ Clin Invest 72: 1058-1063

6. Simpson CMF, Hawthorne JN (1986) Myo-inositol metabolism and $\mathrm{Na}^{+} \mathrm{K}^{+}$-ATPase activity in relation to peripheral nerve function in rats with streptozotocin-induced diabetes. Biochem Soc Trans 14:364-365

7. Greene DA, Lattimer SA (1982) Sodium- and energy-dependent uptake of myo-inositol by rabbit peripheral nerve. Competitive inhibition by glucose and lack of an insulin effect. J Clin Invest 70: 1009-1018

8. Mayhew JA, Gillon KRW, Hawthorne JN (1983) Free and lipid inositol, sorbitol and sugars in sciatic nerve obtained post-mortem from diabetic patients and control subjects. Diabetologia 24: 13-15

9. Greene DA, De Jesus PV, Winegrad AI (1975) Effects of insulin and dietary myoinositol on impaired peripheral motor nerve conduction velocity in acute streptozotocin diabetes. J Clin Invest 55: $1326-1336$

10. Palmano KP, Whiting PH, Hawthorne JN (1977) Free and lipid myo-inositol in tissues from rats with acute and less severe streptozotocin-induced diabetes. Biochem J 167: 229-235

11. Greene DA, Lattimer SA (1986) Protein kinase C agonists acutely normalize decreased ouabain-inhibitable respiration in diabetic rabbit nerve. Implications for $(\mathrm{Na}, \mathrm{K})$-ATPase regulation and diabetic complications. Diabetes 35: 242-245

12. Finegold D, Lattimer SA, Nolle S, Bernstein M, Greene DA (1983) Polyol pathway activity and myo-inositol metabolism. Diabetes 32: $988-992$

13. Gillon KRW, Hawthorne JN, Tomlinson DR (1983) Myo-inositol and sorbitol metabolism in relation to peripheral nerve function in experimental diabetes in the rat: the effect of aldose reductase inhibition. Diabetologia 25: 365-371

14. Gillon KRW, Hawthorne JN (1983) Transport of myo-inositol into endoneurial preparations of sciatic nerve from normal and streptozotocin-diabetic rats. Biochem J 210: 775-781

15. Olsson Y (1984) Vascular permeability in the peripheral nervous system. In: Dyck PJ, Thomas PK, Lambert EH, Bunge R (eds) Peripheral neuropathy, 2nd edn. WB Saunders, Philadelphia, pp 579-597

16. Jacobs JM, MacFarlane RM, Cavanagh JB (1976) Vascular leakage in the dorsal root ganglia of the rat, studied with horseradish peroxidase. J Neurol Sci 29: 95-107

17. Jacobs JM (1977) Penetration of systemically injected horseradish peroxidase into ganglia and nerves of the autonomic nervous system. J Neurocytol 6: 607-618

18. Thomas PK, Wright DW, Tzebelikos E (1984) Amino acid uptake by dorsal root ganglia from streptozotocin-diabetic rats. J Neurol Neurosurg Psychiatry 47:912-916

19. Green RJ, King RHM, Thomas PK, Baron DN (1985) Sodium-potassium ATPase activity in the dorsal root ganglia of rats with streptozotocin-induced diabetes. Diabetologia 28: 104-107

20. Griffin HD, Hawthorne JN (1978) Calcium-activated hydrolysis of phosphatidyl-myo-inositol 4-phosphate and phosphatidylmyo-inositol 4,5-biphosphate in guinea-pig synaptosomes. Biochem J 176: 541-552

21. Sweeley CC, Bentley R, Makita M, Wells WW (1963) Gas-liquid chromatography of trimethylsilyl derivatives of sugars and related substances. J Am Chem Soc 85: 2496-2507

22. Gabbay KH (1973) The sorbitol pathway and the complications of diabetes. N Engl J Med 288: 831-836

23. Moonsammy GI, Stewart MA (1967) Purification and properties of brain aldose reductase and L-hexonate dehydrogenase. $\mathbf{J}$ Neurochem 14: 1187-1193

24. Roach MK (1979) In: Majchrowicz E; Noble E (eds) Biochemistry and pharmacology. Plenum Press, New York, pp 67-80 
25. Baba Y, Kai M, Kamada T, Setoyama S, Otsuji S (1979) Higher levels of erythrocyte membrane microviscosity in diabetes. Diabetes 28: 1138-1140

26. Kamada T, Otsuji S (1983) Lower levels of erythrocyte membrane fluidity in diabetic patients. A spin label study. Diabetes 32: 585-591

27. Boonstra J, Skaper SD, Varon S (1982) Regulation of $\mathrm{Na}^{+} \mathrm{K}^{+}$-pump activity by nerve growth factor in chick embryo dorsal root ganglion cells. J Cell Physiol 113: 28-34

28. Schmidt RE, Modert CW, Yip HK, Johnson EM Jr (1983) Retrograde axonal transport of intravenously administered ${ }^{125}$ I-nerve growth factor in rats with streptozotocin-induced diabetes. Diabetes 32: 654-663

29. Sada HWM, Hughes RD, Gove CD, Williams R (1984) Inhibition of rat brain $\mathrm{Na}^{+} \mathrm{K}^{+}$ATPase activity by serum from patients with fulminant hepatic failure. Hepatology 4: 74-79

30. Simmons DA, Winegrad AI, Martin DB (1982) Significance of tissue myo-inositol concentrations in metabolic regulation in nerve. Science 217: 848-850
31. Simmons DA, Kern EFO, Winegrad AI, Martin DB (1986) Basal phosphatidylinositol turnover controls aortic $\mathrm{Na}^{+} \mathrm{K}^{+}$-ATPase activity. J Clin Invest 77: 503-513

32. Thomas PK, Eliasson S (1984) Diabetic neuropathy. In: Dyck PJ, Thomas PK, Lambert EH, Bunge R (eds) Peripheral neuropathy, 2nd edn. W. B. Saunders, Philadelphia, pp 1771-1810

Received: 10 June 1986;

and in revised form: 24 October 1986

\section{Professor P.K. Thomas}

Department of Neurological Science

Royal Free Hospital School of Medicine

Rowland Hill Street

London NW3 2 PF

UK 